\title{
PENGUATAN PENDIDIKAN \\ NILAI DIBIDANG FIQH; \\ STUDI PEMIKIRAN FALAK \\ KH. ABDUL RANI MAHMUD
}

\author{
MOCH. RIZA FAHMI \\ Fakultas Syariah dan Ekonomi Islam IAIN Pontianak \\ email:riza00100@gmail.com
}

\begin{abstract}
Values education is establishing noble values in a student by a teacher. Values education serves as a support to students to materialize and experience values, and integrate them in his/ her whole life. KH. Abdul Rani Mahmud was an ulema and also a teacher at Madrasah alRaudhatul Islamiyah Pontianak who devoted his life to Islamic education in Pontianak. His concept of Falak was classical, similar to the method developed by earlier ulemas such as Kiai Ma'shum ibn Ali because he used refraction data, declination of the sun, and (standard) old version of equation of time, and did not include the calculation of altitude from the sea level, and determine the time of sunrise and sunset. However, in general his concept of falak in the calculation of the time of prayer is in accordance with astronomy using latitude and longitude data, equation of time, declination of the sun, altitude, and angle of the sun.
\end{abstract}

Keyword: Values Education, KH. Abdul Rani Mahmud

\section{PENDAHULUAN}

Ilmu pendidikan biasa juga disebut pedagogi atau pedagogika adalah suatu disiplin ilmu yang terkait dengan proses pemberadaban, pemberbudayaan dan pendewasaan manusia. Dalam konteks ini pendidikan mempunyai tiga fungsi utama yaitu fungsi integrative, egalitarian dan pengembangan. Dalam konteks ini idealnya pendidikan menjadikan manusia yang beradab, berbudaya dan memiliki nilai-nilai social yang tinggi. Untuk mencapai tujuan pendidikan tersebut tentunya para pendidik tidak hanya memberikan pengajaran yang bersifat kognitif intelektual an sich akan tetapi pendidikan juga harus menyentuh niai-nilai emo- sional dan spiritual peserta didik.

Kita mengenal adanya pendidikan karakter dan pendidikan budi pekerti serta pendidikan nilai yang diharapkan mampu melahirkan generasi-generasi muda bangsa yang memiliki karakter dan memiliki budi pekerti yang baik.

Pendidikan Nilai adalah penanaman nilai-nilai luhur ke dalam diri seorang murid yang diajarkan oleh gurunya. Mardiatmadja dalam Mulyana (2004:119) mendefinisikan pendidikan nilai sebagai bantuan terhadap peserta didik agar menyadari dan mengalami nilai-nilai serta menempatkannya secara integral dalam keseluruhan hidupnya. Pendidikan nilai tidak hanya merupakan program 
khusus yang diajarkan melalui sejumlah mata pelajaran, akan tetapi mencakup keseluruhan program pendidikan.

Berbagai metode pendidikan dan pengajaran yang digunakan dalam berbagai pendekatan lain dapat digunakan juga dalam proses pendidikan dan pengajaran pendidikan nilai. Hal tersebut penting untuk memberi variasi kepada proses pendidikan dan pengajarannya, sehingga lebih menarik dan tidak membosankan.

Dr. Art-Ong Dalam makalahnya yang berjudul "Human Values Integrated Instructional Model" (Model Pembelajaran Nilainilai Kemanusian Terpadu), menuliskan sebuah konsep tentang tujuan model pembelajaran yang menerapkan konsep pendidikan nilai dengan menggunakan suku kata dalam kata EDUCATION yang bermakna sebagai berikut:

E--- singkatan untuk Enlightenment (pencerahan). Ini adalah proses pencapaian pemahaman dari dalam diri atau bathin melalui peningkatan kesadaran menuju pikiran super sadar yang akan memunculkan intuisi, kebijaksanaan, dan pemahaman.

D--- singkatan untuk Duty and Devotion (tugas dan pengabdian). Pendidikan harus membuat siswa menyadari tugasnya dalam hidup. Selain memiliki tugas atau kewajiban yang terhadap orang tua dan keluarga, siswa juga memiliki kewajiban yang berlandaskan cinta kasih dan belas kasih untuk melayani dan menolong semua orang di masyarakat dan di dunia.

U--- singkatan untuk Understanding (pemahaman). Ini bukan hanya mengenai pemahaman terhadap mata pelajaran yang diberikan dalam kurikulum nasional tetapi juga penting untuk memahami diri sendiri.

C--- singkatan untuk Character (karakter). Guru mesti membentuk karekter yang baik pada diri siswa. Seorang yang berkarakter adalah seorang yang memiliki kekuatan moral dan lima nilai kemanusiaan yaitu Kebenaran, Kebajikan, Kedamaian, Kasih sayang dan tanpa Kekerasan. Nilai-nilai kemanusiaan tersebut harus terpadu dalam pembelajatran di kelas.

A--- singkatan untuk Action (tindakan). Para siswa kini belajar dengan giat dan menuangkan pengetahuan yang dipelajarinya dalam ruang ujian dan keluar dengan kepala kosong. Pengetahuan yang mereka peroleh tidak diterapkan dalam tindakan. Pendidikan seperti itu tak berguna. Apapun yang dipelajari siswa mesti diterapkan dalam praktek. Model pembelajaran yang baik mesti membuat hubungan antara yang dipelajari dan situasi nyata dalam hidup. Hal ini akan memungkinkan siswa mengaplikasikan pengetahuan ke dalam hidup mereka sendiri.

T--- singkatan untuk Thanking (berterima kasih). Siswa mesti belajar berterima kasih kepada orang-orang yang telah membantu mereka. Di atas segalanya adalah orang tua yang telah melahirkan dan mengasuh mereka. Siswaharus mengasihi dan menghormati orang tua mereka. Selanjutnya siswa harus berterima kasih kepada guru-guru, karena siswa memperoleh pengetahuan dan kebijaksanaan melalui guru-guru. Maka siswa mesti mengasihi dan menghormati guru. Demikian pula, siswa telah mendapatkan banyak hal dari masyarakat, dari bangsa, dari dunia, dan alam. Siswa mesti selalu berterima kasih kepada semua hal. 
I--- singkatan untuk Integrity (Integritas). Integritas adalah sifat jujur dan karakter menjunjung kejujuran (hornby 1968). Siswa mesti tumbuh menjadi sesorang yang memiliki integritas, yang bisa dipercaya unutk menjadi pemimpin di bidangnya masing-masing.

O--- singkatan untuk Oneness (kesatuan). Pendidikan mesti membantu siswa melihat kesatuan dalam kemajemukan. Apakah kita memiliki agama atau kepercayaan yang berbeda, warna kulit dan ras yang berbeda. Kita mesti belajar hidup damai dan harmonis dengan alam.

N--- singkatan untuk Nobility (kemuliaan). Kemuliaan adalah sifat yang muncul karena memiliki karakter yang tinggi atau mulia. Kemuliaan tidak timbul dari lahir tetapi muncul dari pendidikan. Jadi, kemuliaan terdiri dari semua nilai-nilai yang dijelaskan di atas. ${ }^{1}$

KH. Abdul Rani Mahmud (19121993) sebagai seorang Ulama juga seorang Guru yang mengajar di Madrasah al-Raudhatul Islamiyah Pontianak pada tahun 1939 sampai dengan 1945. Beliau juga pernah menjabat sebagai Kepala Madrasah al-Raudhatul Islamiyah tahun 1947 hingga 1950 (M. Rahmatullah; 2013). Tentunya sebagai seorang guru, beliau memahami dengan benar bagaimana caranya mendidik murid-muridnya. Disini kita ingin mengetahui bagaimana kontribusi pemikiran beliau di bidang pendidikan dan menganalisis pemikiran Falak beliau yang tentunya memberikan penguatan pendidikan nilai kepada ummat Islam di Pontianak dan Indonesia pada umumnya.

1 Sofyan Sauri, Membangun Karakter Bangsa Melalui Pembinaan Profesionalisme Guru Berbasis Pendidikan Nilai, dalam jurnal Pendidikan Karakter, file upi.edu, 2010

\section{RIWAYAT PENDIDIKAN KH. ABDUL} RANI MAHMUD

KH. Abdul Rani Mahmud lahir di Pontianak, tepatnya di Kampung Tambelan Sampit (suatu kampung di pinggiran Sungai Kapuas Pontianak) Kalimantan Barat pada Jum'at Shubuh jam 5, pada 19 Sya'ban 1330 H. bertepatan dengan tanggal 12 Mei 1912 M. (setelah diteliti ternyata bertepatan tanggal 2 Agustus 1912 M). Silsilah keturunannya adalah KH. Abdul Rani Mahmud bin H. Muhammad Arsyad bin Abdurrahman bin Khidir bin Yusuf bin Abdullah (Bujang) bin Syekh Ahmad Al-Hatimy Al-Yamany dari Desa Bani Amir antara Yaman dan Hijaz. (Rahmatullah dan Haitami, 1998).

Masa pendidikan KH. Abdul Rani Mahmud dimulai dengan pelajaran dasar membaca Al-Qur'an yang didapatnya dari orang tuanya sendiri dan datuknya, $\mathrm{H}$. Muhammad Arsyad dan neneknya, setelah itu belajar kepada seorang Tuan Guru Ahmad di Kampung Kuantan dan tamat (khatam) 15 Sya'ban 1337 H. Kemudian dilanjutkan dengan belajar baca-tulis Melayu huruf Arab, juga diajar oleh ayah dan datuknya. Hal ini berlangsung selama lebih kurang empat tahun, yaitu sejak ia berusia 6 tahun sampai 10 tahun (antara tahun 1918 sampai 1922).

Pendidikan yang ditempuh selanjutnya adalah Sekolah Gubernemen di Pontianak selama 5 tahun (tahun 1923 - 1928), dan tamat dengan sertifikat. Ia sekolah Gubernemen pada pagi hari dan sore harinya ia masih tetap melanjutkan pelajarannya yaitu Pengajian Alqur'an dan pelajaran Agama Islam. Malam hari ia gunakan waktunya untuk belajar Seni budaya Islam diantaranya membaca Maulid, Barzanji, Nazham, Syarafal-Anam, Hadhrah dengan lagunya masing-masing, serta jepin dengan gambusnya. Sehingga tidak heran kalau ia sangat mahir sekali dalam "Seni Bu- 
daya Islam" yang telah dipelajarinya.

KH. Abdul Rani Mahmud menggunakan sebagian besar waktunya untuk belajar dari pagi, sore hingga malam hari. Ia sangat haus akan ilmu; baik ilmu agama Islam maupun lainnya. Pada usia 17 tahun beliau belajar Kitab-kitab yang berbahasa Arab seperti Ilmu Bahasa Arab (Nahwu, Sharf, Ma'ani, Bayan, Badi' dan sebagainya), Tauhid, Mantiq, Fiqh dan Tasawuf.

Ia belajar pada pagi, sore dan malam hari di Surau-surau Tuan guru yang hidup pada masa itu (tahun 1929 - 1936). Ia belajar Ilmu-ilmu di atas pada Tuan Guru H. Thaha di Kampung Banjar Serasan, Tuan Guru H. Ismail Jabal, Tuan Guru H. Muhammad di Kampung Tambelan. Pontianak. (Mahmud 1984 : 1). Dari para Tuan Guru inilah beliau belajar ilmu falak seperti hisab urfy, hisab haqiqy dan rubu' mujayyab. Walaupun tidak disebutkan secara langsung silsilah (sanad) ilmu falak yang beliau pelajari secara langsung tetapi beliau pernah menyatakan bahwa yang pertama menyebarkan ilmu falak di Pontianak adalah H. Ismail al-Kelantani seorang Ulama besar yang pernah menjadi mufti kerajaan Pontianak pada tahun 1910.

Karya-karyanya itu sebagian besar erat kaitannya dengan bidang Fiqh, hal ini dikarenakan beliau sangat tertarik di bidang ini tanpa mengabaikan bidang keagamaan yang lainnya, seperti Tauhid, Tasawuf, Tarekat, Akhlaq, Al-Qur'an dan Tafsir, Hadits dan lainnya. Hanya saja bidang Fiqh yang lebih banyak ia tekuni, yaitu dengan mengkaji atau membaca Kitab-Kitab Kuning (Klasik) yang ada hubungannya dengan bidang Fiqh kemudian menguraikannya kedalam tulisan

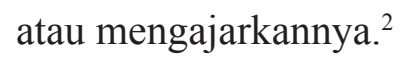

2 Rahmatullah, M dan Haitami Salim. Artikel Biografi $H$. Abdul Rani Mahmud, Stain Pontianak Press, 2005
Di bidang pendidikan beliau adalah seorang Guru Madrasah al-Raudhatul Islamiyah (1939-1945), Guru Sekolah Menengah Islam Pertama (1954-1958), Guru Sekolah persiapan IAIN Pontianak (1962-1965), Dosen Fakultas Tarbiyah Institut Agama Islam Swasta Pontianak (1965-1968), Pengasuh dan Pengajar Majelis Ta'lim al-Ihsan (1969-1993). ${ }^{3}$

Jadwal salat sepanjang masa ini beliau buat sekitar tahun 1970-an dan telah tersebar di seluruh masjid dan musholla di Kalimantan Barat. Jika dilihat dari tahun pembuatannya maka jadwal ini berusia 40 tahunan (19702012) dan sampai hari ini masih digunakan oleh pengurus-pengurus masjid dan musholla kota Pontianak dan masyarakat Kalimantan barat pada umumnya.

\section{HISAB AWAL WAKTU SALAT KH. ABDUL RANI MAHMUD}

Perhitungan awal waktu salat yang tercatat dalam tulisan tangan Ustadz Abdurrahman (murid KH. Abdul Rani Mahmud) yang peneliti dapatkan ini ditulis ketika beliau belajar ilmu falak dengan KH. Abdul Rani Mahmud pada tahun 1960an. Tidak diketahui kitab apa yang menjadi rujukan dalam buku ini akan tetapi dalam menyusun dan menghitung jadwal salat sepanjang masa, beliau (KH. Abdul Rani Mahmud) menggunakan rujukan seperti yang telah diajarkannya kepada Ustadz Abdurrahman. ${ }^{4}$

Pada sampul buku ustadz Abdurrahman tertulis bahwa buku ini bernama jadwal falak. Adapun buku ini berisikan:

1. Tabel-tabel jadwal tinggi matahari (thulus

3 Rahmatullah, M, Pemikiran Fiqh H. Abdul Rani Mahmud, STAIN Press, 2013

4 Wawancara dengan Ustadz Abdurrahman pada tanggal 25 February 2012 dirumah beliau daerah Sungai Nipah Kecamatan Jeruju Besar Kab. Kubu Raya Kalimantan Barat. 
syamsi) dari bulan januari sampai desember beserta tanggalnya

2. Table jadwal deklinasi diambil dari tinggi matahari (almail yu'khadzu bi tuulis syams)

3. Table jadwal perata waktu (ta'diluz zaman) menurut kalender bulan al ifrinji (Gregorius).

4. Table jadwal busur siang (nishful qaus)

5. Tabel jadwal waktu zuhur (hissah zuhur) berdasarkan bulan dan tanggal.

6. Tabel data Lintang dan Bujur Tempat wilayah Indonesia dan diluar Indonesia melalui Kota Greenwich.

7. Contoh perhitungan awal waktu salat zuhur, ashar, maghrib, isya dan subuh.

8. Contoh perhitungan arah kiblat

Tulisan Ustadz Abdurrahman berupa bahasa Arab dan bahasa Melayu untuk nama-nama daerah dan angka-angka didalam table beliau isi dengan angka latin $(1,2,3)$.

Dalam memberikan contoh perhitungan awal waktu salat, buku ini menggunakan daerah Pondok Tanjung, Perak Malaysia ( 0500" LT, $100^{\circ} 44^{\prime \prime B T) . ~}$

1. Perhitungan Awal Waktu Zuhur (Mencari Nishful Qaus daerah Pondok Tanjung 05 LT dengan deklinasi $+23^{\circ} 27^{\prime}$ pada tanggal 23 Juni dan deklinasi $-23^{\circ} 27^{\prime}$ pada tanggal 23 Desember)

\begin{tabular}{|c|c|c|}
\hline & 23 Juni & 23 Des \\
\hline $\begin{array}{l}\text { Data Deklinasi (Tamam al- } \\
\text { mail al-mawafiq) }\end{array}$ & 66.33 & 113.27 \\
\hline $\begin{array}{l}\text { Lintang Tempat } 05^{\circ}-90^{\circ} \\
\text { (tamam al-'urdh) }\end{array}$ & 85.00 & 85.00 \\
\hline Altitude (al-irtifa') & 91.00 & 91.00 \\
\hline Jumlah & $242.33 / 2$ & $289.27 / 2$ \\
\hline Al-Mahfuz & 121.16 & 144.43 \\
\hline Data deklinasi & 66.33 & 113.27 \\
\hline $\begin{array}{l}\text { Jumlah al-mahfuz pada } \\
\text { data deklinasi (dikurangi) }\end{array}$ & 54.33 & 31.16 \\
\hline Al-Mahfuz & 121.16 & 144.43 \\
\hline
\end{tabular}

\begin{tabular}{|c|c|c|}
\hline Data tamam al-urdh & 85.00 & 85.00 \\
\hline $\begin{array}{l}\text { Jumlah al-Mahfuz pada } \\
\text { data tamam al-urdh } \\
\text { (dikurangi) }\end{array}$ & 36.16 & 59.43 \\
\hline $\begin{array}{l}\text { Nilai Sin data deklinasi } \\
\text { (al-jaibah litamaamil mail) }\end{array}$ & 9.96 .26 & 9.96 .26 \\
\hline $\begin{array}{l}\text { Nilai Sin data lintang } \\
\text { tempat (al-jaibah } \\
\text { litamaamilurdh) }\end{array}$ & 9.99 .83 & 9.99 .83 \\
\hline Jumlah & 99.609 & 99.609 \\
\hline Ad-darul a'syaar & 10.0000 & 10.0000 \\
\hline Jumlah sisanya (dikurangi) & 0.0391 & 0.0391 \\
\hline $\begin{array}{l}\text { Nilai sin al-mahfuz } \\
\text { litamaamil mail }\end{array}$ & 9.9119 & 9.7152 \\
\hline $\begin{array}{l}\text { Nilai sin al-mahfuz } \\
\text { litamaamil urdh }\end{array}$ & 9.7720 & 9.9363 \\
\hline Jumlah & $197.23 .30 / 2$ & $196906 / 2$ \\
\hline Hasil pembagian & 98.615 & 98.453 \\
\hline Busur siang (Qaus nisfu) & $46^{\circ} 38^{\prime}$ & $44^{\circ} 27^{\prime}$ \\
\hline Konversi menjadi jam & \multicolumn{2}{|c|}{$1^{0} 33^{\prime} 14^{\prime \prime} \times 41^{0} 28^{\prime} 54^{\prime \prime} \times 4$} \\
\hline Hasil (nishful qausil mar’i) & $6^{0} 12^{\prime} 56^{\prime \prime}$ & $5^{0} 55^{\prime} 34^{\prime \prime}$ \\
\hline Hissah zuhur & Jam 12.02 & Jam 11.59 \\
\hline $\begin{array}{l}\text { Selisih menit bujur } \\
\text { (daqaaiq farqa at-thul) }\end{array}$ & 36 & 36 \\
\hline $\begin{array}{l}\text { Waktu Zuhur di Pondok } \\
\text { Tanjung (UTC+8/ Malaysia) }\end{array}$ & 12. 38 & 12.35 \\
\hline
\end{tabular}

2. Perhitungan Awal Waktu Ashar

$\begin{array}{lcc} & \text { 23 Juni } & 23 \text { Des } \\ \begin{array}{lcc}\text { Titik kulminasi (ghayatul } \\ \text { irtifa' lilmail al-mawafiq) }\end{array} & 71.33 & 61.33 \\ \begin{array}{l}\text { Tinggi Kulminasi (tamam } \\ \text { al-ghayatul irtifa') }\end{array} & 18.27 & 28.27 \\ \begin{array}{l}\text { Nilai tangens (zillu a'syaari } \\ \text { tamaamul ghayah) }\end{array} & 0.3337 & 0.5418 \\ \begin{array}{l}\text { Nilai tangens } \\ \text { Ketinggian ashar (Dhil Asar) }\end{array} & 1.3337 & 1.5418 \\ \begin{array}{l}\text { Nilai Tangens ketinggian } \\ \text { ashar (azzhil al a'syar) }\end{array} & 53^{\circ} 08^{\prime} & 57^{\circ} 02^{\prime} \\ \begin{array}{l}\text { Data deklinasi } \\ \text { Data Lintang }\end{array} & 66.33 & 113.27 \\ \begin{array}{l}\text { Jumlah } \\ \text { Jumlah (al-Mahfuz ) }\end{array} & 85.00 & 85.00 \\ \text { Data deklinasi } & 102.20 & 127.44 \\ & 66.33 & 113.27\end{array}$


Jumlah setelah dikurangi data deklinasi (fadhlul mahfuz litamaamilmail)

Almahfuz

Data Lintang

Jumlah setelah dikurangi data lintang (fadhlul mahfuz litamamil urdh) Nilai sin deklinasi (aljaibah litamaamil mail)

Nilai sin lintang (aljaibah litamaamil urdh)

Jumlah

Ad-darul a'syaar

Sisa

Nilai sin pada jumlah deklinasi (jaibah fadhlul mahfuz litamaamil mail) Nilai sin pada jumlah lintang (jaibah fadhlul mahfuz litamaamil urdh)

Jumlah

Separuh jumlah

Separuh busur (qaus nisfu)

Jumlah wilayah ashar

(fadhlul daairul ashar)

Konversi ke jam wilayah

ashar

Waktu zuhur (UTC +8)

Waktu ashar (UTC +8)

$\begin{array}{cc}35.47 & 14.17 \\ 102.20 & 127.44 \\ 85.00 & 85.00 \\ 17.20 & 42.44 \\ 9.9626 & 9.9626 \\ 9.9983 & 9.9983 \\ 9.9609 & 9.9609 \\ 10.0000 & 10.0000 \\ 391 & 391\end{array}$

$9.7670 \quad 9.3921$

$9.4741 \quad 9.8316$

$19.2802 / 2 \quad 19.2628 / 2$

$96.401 \quad 96.314$

$25^{\circ} 53^{\prime} \quad 25^{\circ} 20^{\prime}$

$51^{\circ} 46^{\prime} \quad 50^{\circ} 40$

$3.27 .04 \quad 3.22 .04$

$12.38 \quad 12.35$

16.05

3. Perhitungan awal waktu maghrib

$\begin{array}{lcc} & \text { 23 Juni } & \begin{array}{c}23 \\ \text { Desember }\end{array} \\ \begin{array}{l}\text { Data Deklinasi (Tamam al- } \\ \text { mail al-mawafiq) }\end{array} & 66.33 & 113.27 \\ \begin{array}{l}\text { Lintang Tempat 050-90 } \\ \text { (tamam al-'urdh) }\end{array} & 85.00 & 85.00 \\ \begin{array}{l}\text { Altitude (al-irtifa') } \\ \text { Jumlah }\end{array} & 91.00 & 91.00 \\ \begin{array}{l}\text { Al-Mahfuz } \\ \begin{array}{l}\text { Data deklinasi } \\ \text { Jumlah al-mahfuz pada } \\ \text { data deklinasi (dikurangi) }\end{array}\end{array} & 242.33 / 2 & 289.27 / 2 \\ & 121.16 & 144.43 \\ & 66.33 & 113.27 \\ & & 31.16\end{array}$

1. Perhitungan awal waktu Isya

Al-Mahfuz

Data Lintang (tamam al-

urdh)

Jumlah al-Mahfuz pada

data Lintang (dikurangi)

Nilai Sin data deklinasi (al-

jaibah litamaamil mail)

Nilai Sin data lintang

tempat (al-jaibah

litamaamilurdh)

Jumlah

Ad-darul a'syaar

Jumlah (dikurangi)

Nilai sin al-mahfuz

litamaamil mail

Nilai sin al-mahfuz

litamaamil urdh

Jumlah

Hasil pembagian

Qaus nisfu

Konversi menjadi jam

Hasil (nishful qausil mar'i)

Hissah zuhur

Selisih menit bujur

Waktu Zuhur di Pondok

Tanjung (UTC+8)

Separuh busur siang

(nishful qaus al-mar'i)

Waktu Maghrib (UTC +8)
121.16

144.43

$85.00 \quad 85.00$

$36.16 \quad 59.43$

$9.96 .26 \quad 9.96 .26$

$9.99 .83 \quad 9.99 .83$

$99.609 \quad 99.609$

$10.0000 \quad 10.0000$

$0.0391 \quad 0.0391$

$9.9119 \quad 9.7152$

$9.7720 \quad 9.9363$

$197.23 .30 / 2 \quad 196906 / 2$

$98.615 \quad 98.453$

$46^{\circ} 38^{\prime} \quad 44^{\circ} 27^{\prime}$

$1^{0} 33^{\prime} 14^{\prime \prime}$ x $41^{0} 28^{\prime} 54^{\prime \prime}$ x 4

612'56" $\quad 5^{\circ} 55^{\prime} 34^{\prime \prime}$

Jam 12.02 Jam 11.59

36

36

12. 38

12.35

6.13

5.56

$18.51 \quad 18.31$
Altitude haqiqi (Tamam alirtifa' haqiqi)

23 Juni 23 Des

$90.00 \quad 90.00$

$44.00 \quad 16.00$

'urdh)

Semi diameter matahari

(al-irtifa')

Matahari

16

16

17.00

17.00

Altitude waktu isya (tamam al-irtifa' li waqti al-isya)

108.00

108.00

Data deklinasi

66.33

113.27

Data lintang tempat

85.00

85.00 


\begin{tabular}{|c|c|c|c|c|c|}
\hline Jumlah & $259.33 / 2$ & $306.27 / 2$ & $\begin{array}{l}\text { Data Lintang (tamam al- } \\
\text { urdh) }\end{array}$ & 85.00 & 85.00 \\
\hline Separuh jumlah (almahfuz) & 129.46 & 153.13 & Jumlah & $261.33 / 2$ & $308.27 / 2$ \\
\hline Data deklinasi & 66.33 & 113.27 & Separuh jumlah (nisful & 130.46 & 154.13 \\
\hline $\begin{array}{l}\text { Jumlah al-mahfuz pada } \\
\text { deklinasi }\end{array}$ & 63.13 & 39.46 & majmu/al-mahfuz) & & \\
\hline & & & Data deklınası & 66.33 & 113.21 \\
\hline Data lintang tempat & 129.46 & 153.13 & $\begin{array}{l}\text { Jumlah setelah dikurangi } \\
\text { deklinasi }\end{array}$ & 64.13 & 40.46 \\
\hline Jumlah almahfuz pada & & & Almahfuz & 130.46 & 154.13 \\
\hline lintang & 44.46 & 68.13 & Data lintang tempat & 85.00 & 85.00 \\
\hline $\begin{array}{l}\text { Nilai Sin data deklinasi (al- } \\
\text { jaibah litamaamil mail) }\end{array}$ & 9.96 .26 & 9.96 .26 & $\begin{array}{l}\text { Jumlah al-Mahfuz pada } \\
\text { data Lintang (dikurangi) }\end{array}$ & 45.46 & 69.13 \\
\hline $\begin{array}{l}\text { Nilai Sin data lintang (al- } \\
\text { jaibah litamaamil urdh) }\end{array}$ & 9.99 .83 & 9.99 .83 & $\begin{array}{l}\text { Nilai Sin data deklinasi (al- } \\
\text { jaibah litamaamil mail) }\end{array}$ & 9.96 .26 & 9.96 .26 \\
\hline Addarul a'syaar & 10.0000 & 9.9609 & $\begin{array}{l}\text { Nilai Sin data lintang } \\
\text { tempat (al-jaibah } \\
\text { litamaamilurdh) }\end{array}$ & 9.99 .83 & 9.99 .83 \\
\hline Sisa (kurang) & 391 & 391 & Jumlah & 99.609 & 99.609 \\
\hline $\begin{array}{l}\text { Nilai sin jumlah almahfuz } \\
\text { pada deklinasi }\end{array}$ & 9.9507 & 9.8059 & $\begin{array}{l}\text { Satu Daur (Ad-darul } \\
\text { a'syaar) }\end{array}$ & 10.0000 & 10.0000 \\
\hline Nilai sin jumlah almahfuz & 9.8477 & 9.9678 & Jumlah (dikurangi) & 0.0391 & 0.0391 \\
\hline pada lintang & & & $\begin{array}{l}\text { Nilai sin al-mahfuz } \\
\text { litamaamil mail }\end{array}$ & 9.9545 & 9.8146 \\
\hline Separuh jumlah & 99.187 & 99.064 & $\begin{array}{l}\text { Nilai sin al-mahfuz } \\
\text { litamaamil urdh }\end{array}$ & 9.8552 & 9.9707 \\
\hline Separuh busur (qaus nisfu) & $56^{\circ} 01^{\prime}$ & $53^{\circ} 43^{\prime}$ & Jumlah & $198.488 / 2$ & $198.247 / 2$ \\
\hline Konversi ke Jam & $1.52 .02 \times 4$ & $1.47 .26 \times 4$ & Hasil pembagian & 99.244 & 99.123 \\
\hline Jam wilayah isya & 7.28 .08 & 7.09 .44 & Nilai sin (Qaus nisfu) & $57^{\circ} 10^{\prime}$ & $54^{\circ} 48^{\prime}$ \\
\hline $\begin{array}{l}\text { Waktu Zuhur di Pondok } \\
\text { Tanjung (UTC }+8)\end{array}$ & 12.38 & 12.35 & Konversi menjadi jam & $1^{\circ} 54^{\prime} 20^{\prime \prime} \times 4$ & $1^{\circ} 49^{\prime} 36^{\prime \prime} \times 4$ \\
\hline Waktu isya (UTC+8) & 20.06 & 19.44 & daairul fajri) & $7^{\circ} 37^{\prime} 20^{\prime \prime}$ & $7^{0} 18^{\prime} 24^{\prime \prime}$ \\
\hline \multicolumn{3}{|l|}{ 2. Perhitungan waktu fajar } & $\begin{array}{l}\text { Waktu Zuhur di Pondok } \\
\text { Tanjung (UTC +8/Malaysia) }\end{array}$ & 12. 38 & 12.35 \\
\hline 2. & 23 Juni & 23 Des & $\begin{array}{l}\text { Waktu terbitnya fajar (UTC } \\
+8 \text { ) }\end{array}$ & 05.01 & 05.17 \\
\hline $\begin{array}{l}\text { Altitude dari ufuq hakiki } \\
\text { (al-irtifa' anil ufuqi haqiqi) }\end{array}$ & 90.00 & 90.00 & Ihtiyath & $00^{\circ} 20^{\prime}$ & $00^{\circ} 20^{\prime}$ \\
\hline Jarak ufuq mar'l dari ufuk & & & Waktu imsak (UTC +8) & 04.41 & 04.57 \\
\hline $\begin{array}{l}\text { haqiqi (inhithootul ufuqi } \\
\text { mar'l 'anil haqiqi) }\end{array}$ & 44.00 & 44.00 & & & \\
\hline $\begin{array}{l}\text { Semi diameter matahari } \\
\text { (nishfu quthri syamsi) }\end{array}$ & 16.00 & 16.00 & \multirow{4}{*}{\multicolumn{3}{|c|}{$\begin{array}{l}\text { KOMPONEN PERHITUNGAN } \\
\text { WAKTU SALAT KH. ABDUL RANI } \\
\text { MAHMUD } \\
\text { Perhitungan untuk awal waktu salat } \\
\text { dalam buku tulisan Ustadz Abdurrahman } \\
\text { pada prinsipnya tidak jauh berbeda dengan } \\
\text { perhitungan awal waktu salat yang lain, le- }\end{array}$}} \\
\hline Wilayah fajar (daairul fajri) & 19.00 & 19.00 & & & \\
\hline $\begin{array}{l}\text { Puncak altitude pada waktu } \\
\text { fajar }\end{array}$ & 110.00 & 110.00 & & & \\
\hline Data deklinasi & 66.33 & 113.27 & & & \\
\hline
\end{tabular}


tak perbedaannya hanya pada sumber dan rumus yang digunakan. Sebelum melakukan perhitungan waktu salat data yang diperlukan untuk kepentingan menghitung waktu salat untuk suatu daerah adalah :

\section{Koordinat Lintang Tempat ( $\boldsymbol{\varphi})$ dan Bujur Tempat $(\boldsymbol{\lambda})$ Daerah}

Jarak antara katulistiwa atau equator sampai garis lintang diukur sepanjang garis meridian disebut lintang tempat atau lintang geografis atau urdhul balad yang dalam astronomi dilambangkan dengan $\varphi$ (phi). Lintang tempat bagi tempat-tempat (kota) yang berada di utara equator disebut Lintang Tempat Utara atau Lintang Utara (LU) dan bertanda positif $(+)$. Lintang tempat bagi tempat-tempat (kota) yang berada di selatan equator disebut Lintang Tempat Selatan atau Lintang Selatan (LS) dan bertanda negative (-). Harga Lintang Tempat Utara adalah $0^{\circ}$ sampai $90^{\circ}$, yakni $0^{\circ}$ bagi tempat yang tepat di equator seperti Kota Pontianak sedangkan $90^{\circ}$ tepat di kutub utara. Sedangkan harga Lintang Tempat Selatan adalah $0^{\circ}$ sampai $-90^{\circ}$, yakni $0^{\circ}$ adalah bagi tempat yang tepat di equator sedangkan $-90^{\circ}$ tepat di titik kutub selatan. (Khazin, 2004:40).

Adapun Bujur Tempat adalah jarak yang diukur sepanjang busur equator dari bujur yang melalui kota Greenwich sampai bujur yang melalui tempat atau negeri dimaksud. Bujur Tempat ini dalam bahasa Inggris biasa diistilahkan dengan Longtitude dan dalam bahasa Arab diistilahkan Thul al-balad, sedangkan Siradj Dahlan mengistilahkan Moedjor. Tanda astronomisnya $\lambda$ (lambda). (Azhari, 2008:47).

Lintang Tempat dan Bujur Tempat dalam buku ustadz Abdurrahman selisihnya tidak jauh berbeda dengan data Lintang Tempat atau Bujur Tempat yang ada pada saat ini, seperti kota Pontianak memiliki Lintang Tempat $0^{\circ} 02^{\prime}$, Bujur Tempat $109^{\circ} 20^{\prime}$ dalam buku beliau sedangkan data sekarang kota Pontianak $0^{\circ} 05^{\prime}$ dan Bujur Tempat $109^{\circ} 22^{\prime}$. Nama-nama kota tertulis dalam bahasa Arab melayu seperti gambar dibawah ini.

Table sebelah kanan dengan tulisan Arab Melayu adalah nama-nama kota seperti Kota Raja Sumatera, Kota Pinang, Kuala Lumpur, Pontianak, Surabaya, Betawi Jawa (Jakarta), Bandung, Garut, Cirebon, Pekalongan, Semarang, Kudus, Sumenep, Banyuwangi, Sumbawa, Kupang dan paling bawah kanan Ternate Maluku. Adapun kata Urdhun artinya Lintang Tempat dan Thulun artinya Bujur Tempat.

\section{Tabel Hissah Zuhur (Meridian Pass)}

Data ini ditulis dalam bentuk tabel yang berisikan jam (dalam satuan jam dan menit) dan bulan-bulan masehi serta tanggal hariannya. Seperti tanggal 01 Januari waktu hakiki zuhur (hissah zuhur) pada pukul 12 . 03 sampai 31 Desember pada pukul 12. 03. Jadi ketika kita menghitung awal waktu salat zuhur pada tanggal 05 Januari maka data waktu zuhur hakikinya pukul 12. 05 ditambah atau dikurangi dengan selisih bujur tempat daerah yang dimaksud.

Setelah peneliti melihat bahwa data ini dibuat berdasarkan waktu hakiki ( jam 12 tepat) dikurangi dengan data yang tersedia di tabel perata waktu (equation of time). Contoh pada tanggal 01 january $12^{-}-00^{\circ} 3$ '21' (data equation of time sesuai dengan buku ini) hasilnya adalah $12^{\circ} 03^{\prime}$ sama dengan data hissah zuhur. Kemudian pada tanggal 15 Desember $12-00^{\circ} 5$, $8^{\prime \prime}$ hasilnya adalah $11^{\circ}$ 54' 52" (digenapkan menjadi 11.55) Adapun tabelnya seperti gambar dibawah ini :

\section{Tabel Perata Waktu (Ta'dilul az-Zamaan)}


Equation of time atau Ta'dilul Zaman yang diterjemahkan dengan perata waktu, yaitu selisih waktu antara waktu matahari hakiki dengan waktu matahari rata-rata (pertengahan). Dalam ilmu falak biasa dilambangkan dengan huruf $e$ (kecil). Waktu matahari hakiki adalah waktu yang berdasarkan pada perputaran bumi pada sumbunya yang sehari semalam tidak tentu 24 jam melainkan kadang kurang dan kadang lebih dari 24 jam. (Khazin, $2004: 67$ ).

Tabel dalam buku ini berisikan tanggal, bulan-bulan masehi dan satuan menit dan detik. Seperti tanggal 01 January memiliki equation of time - 3'21' (-3 menit 21 detik) sampai 31 Desember -2' 45". Peneliti menelusuri bahwa data perata waktu dalam buku ini selisihnya (kurang lebih 1-5 detik) dengan data winhisab 2010 pada tahun 1970. Adapun Tanda (-) dalam buku ini artinya negative dan tanda (=) artinya positif. Seperti gambar dibawah ini :

\section{Tabel Deklinasi Matahari, Tabel Menit-} Menit Refraksi ${ }^{5}$ dan Semi Diameter ${ }^{6}$.

Deklinasi matahari atau mailu syams adalah jarak sepanjang lingkaran deklinasi

5 Refraksi yaitu perbedaan antara tinggi suatu benda langit yang dilihat dengan tinggi sebenarnya diakibatkan adanya pembiasan sinar. Pembiasan ini terjadi karena sinar yang dipancarkan benda tersebut dating ke mata melalui lapisan-lapisan atmosfir yang berbeda-beda tingkat kerenggangan udaranya, sehingga posisi setiap benda langit itu terlihat lebih tinggi dari posisi sebenarnya. Benda langit yang sedang menempati titik zenith refraksinya $0^{\circ}$, semakin rendah posisi suatu benda langit, refraksinya semakin besar, dan refraksi itu mencapai nilai yang paling besar (yaitu sekitar 34',5) pada saat piringan atas benda langit itu bersinggungan dengan kaki langit. Dalam bahasa Arab refraksi bisa diistilahkan dengan al-inisari al-jawiy atau daqaaiq al-ikhtilaf. (Azhari, 2008:180)

6 Jari-jari, Nishful quthr (Ar) atau radius (Ing) yaitu jarak titik pusat matahari dengan piringan luarnya. Data ini perlu diketahui untuk menghitung secara tepat saat matahari terbenam, matahari terbit dan sebagainya. (Azhari, 2008:191) dihitung dari equator sampai matahari. Dalam astronomi dilambangkan dengan $\delta$ (delta). Apabila matahari berada di sebelah utara equator maka deklinasi matahari bertanda positif $(+)$ dan apabila matahari berada di sebelah selatan equator maka deklinasi matahari bertanda negative (-). Harga atau nilai deklinasi matahari ini, baik positif ataupun negative adalah $0^{\circ}$ sampai sekitar $23^{\circ} 27^{\prime}$. Harga deklinasi $0^{\circ}$ terjadi pada setiap tanggal 21 Maret dan 23 September. Selama waktu (21 Maret sampai 23 September) deklinasi matahari positif, dan selama waktu ( 23 September sampai 21 Maret) deklinasi matahari bertanda negative. (Khazin, 2004:66).

Dalam buku ini data deklinasi matahari berisikan tanggal, bulan berdasarkan zodiac atau rasi bintang (buruj) dan nilai deklinasinya. Jika dalam Winhisab ephemeris 2010 data deklinasi matahari pada tahun 1970 dimulai dengan nilai $-23^{\circ} 03$ 'pada tanggal 01 januari 1970 maka buku ini dimulai dengan nilai $-23^{\circ}$ 27', maka bulan Januari sampai Mei selisihnya 2-5 derajat, bulan Juni sampai Agustus 1-2 derajat, bulan September sampai November 2-3 derajat, dan Desember 1 derajat. Adapun tabelnya seperti gambar dibawah ini :

Perhitungan awal waktu salat yang tercatat dalam tulisan tangan Ustadz Abdurrahman (murid KH. Abdul Rani Mahmud) ini ditulis ketika beliau belajar ilmu falak dengan KH. Abdul Rani Mahmud pada tahun 1960an. Tidak diketahui kitab apa yang menjadi rujukan dalam buku ini akan tetapi dalam menyusun dan menghitung jadwal salat sepanjang masa, beliau (KH. Abdul Rani Mahmud) menggunakan rujukan seperti yang telah diajarkannya kepada Ustadz Abdurrahman.

\section{KESIMPULAN}

Pemikiran falak KH. Abdul Rani 
Mahmud termasuk dalam kategori hisab klasik sama seperti metode perhitungan waktu salat karya ulama-ulama terdahulu seperti metode Syawariq al-Anwar karya Kyai Noor Ahmad Jepara, Kitab Durus al-Falakiyah karya Syekh Ma'shum bin Ali, Kitab al-Khulashah al-Wafiyyah karya Kyai Zubair Umar Jailani dll. Kelebihan metode perhitungan awal waktu salat H. Abdurrani Mahmud yaitu telah menggunakan data-data astronomi seperti ta'dilul zaman (perata waktu), mail asysyams (deklinasi matahari), irtifa' (altitude) dan koordinat lintang bujur, tentunya metode perhitungan awal waktu salat ini merupakan metode hisab terbaik dan modern pada zamannya.

Pendidikan nilai yang KH. Abdul Rani Mahmud berikan kepada kita adalah semangat mendidik, pengajar, pembimbing dan demonstrator yang ulung dan menempatkannya secara integral dalam keseluruhan hidupnya. Hal itu dibuktikannya dengan hasil karya terbesarnya (magnum opus) dibidang falak yaitu jadwal salat sepanjang masa yang bisa dirasakan manfaatnya hingga saat ini.

\section{DAFTAR PUSTAKA}

Azhari, Susiknan, Ilmu Falak Perjumpaan Khazanah Islam dan sains

Modern, Yogyakarta, suara Muhammadiyah, 2007.

Khazin, M , Ilmu Falak dalam Teori dan Praktik, Yogyakarta: Buana Pustaka, 2004.

Mulyana, Rohmat, Mengartikulasikan Pendidikan Nilai, Bandung, Alfabeta, 2004.
Na-Ayudha, Art-Ong Jumsai B.A., M.A., D.I.C. Model Pembelajaran Nilai-nilai

Kemanusian Terpadu. Yayasan Pendidikan Sathya Sai Indonesia, 2008.

Rajasa, Hatta. Membangun Karakter dan Kemandirian Bangsa (Makalah), 2007.

Rahmatullah, M, Pemikiran Fiqh H. Abdul Rani Mahmud, STAIN Press, 2013.

Rahmatullah,M dan Haitami Salim, Biografi H. Abdurrani Mahmud, STAIN Pontianak, Kalimantan Barat, 2005.

Sauri, Sofyan, Membangun Karakter Bangsa Melalui Pembinaan Profesionalisme Guru Berbasis Pendidikan Nilai, dalam jurnal Pendidikan Karakter, file upi.edu, 2010. 